\title{
Retraction Note: Decreased miR-154 expression and its clinical significance in human colorectal cancer
}

\author{
Yang Kai ${ }^{1}$, Cheng Qiang ${ }^{2}$, Pan Xinxin ${ }^{1}, Z^{2}$ hou Miaomiao ${ }^{1}$ and Lin Kuailu ${ }^{1 *}$
}

\section{Retraction note: World J Surg Oncol}

\author{
https://doi.org/10.1186/s12957-015-0607-5
}

The Editor-in-Chief is retracting this article [1] due to overlap with the following articles (amongst others) [2-6].

None of the authors have responded to any correspondence from the Editor-in-Chief or publisher about this retraction.

\section{Author details \\ 'Department of Surgical Oncology, The First Affiliated Hospital of Wenzhou Medical College, Wenzhou 325000, China. ${ }^{2}$ Department of neurology, Huai'an} No. 2 Hospital, Huai'an, Jiangsu Province, China.

Published online: 14 June 2019

\section{References}

1. Kai Y, Qiang C, Xinxin P, Miaomiao Z, Kuailu L. Decreased miR-154 expression and its clinical significance in human colorectal cancer. World J Surg Oncol. 2015;13:195.

2. Zhu, et al. Decreased microRNA-224 and its clinical significance in non-small cell lung cancer patients. Diagn Pathol. 2014;(9):198 http:// diagnosticpathology.biomedcentral.com/articles/10.1186/s13000-014-0198-4.

3. Fo, et al. MiR-206 functions as a tumor suppressor and directly targets K-Ras in human oral squamous cell carcinoma. OncoTargets and Therapy. 2014;7 https://www.dovepress.com/front_end/mir-206-functions-as-a-tumorsuppressor-and-directly-targets-k-ras-in\%2D\%2Dpeer-reviewed-article-OTT.

4. Tang M, et al. MicroRNA-145 downregulation associates with advanced tumor progression and poor prognosis in patients suffering osteosarcoma. OncoTargets Therapy. 2013;6:833-8 https://www.dovepress.com/microrna145-downregulation-associates-with-advanced-tumor-progression-peerreviewed-article-OTT.

5. Ye, et al. miRNA-27b targets vascular endothelial growth factor $C$ to inhibit tumor progression and angiogenesis in colorectal Cancer. Plos One. 2013. https://journals.plos.org/plosone/article?id. https://doi.org/10.1371/journal. pone.0060687.

6. Sun, et al. The microRNA-217 functions as a tumor suppressor and is frequently downregulated in human osteosarcoma. Biomed Pharmacother. 2015;71:58-63 http://www.sciencedirect.com/science/article/pii/

S0753332215000633?np=y\&npKey=

36a5e61c240440f5c791ebb330c69e53b99cf4b599d8cf35805ed8498bb593a4.

\footnotetext{
*Correspondence: manulinkl@163.com

'Department of Surgical Oncology, The First Affiliated Hospital of Wenzhou Medical College, Wenzhou 325000, China

Full list of author information is available at the end of the article
}

(c) The Author(s). 2019 Open Access This article is distributed under the terms of the Creative Commons Attribution 4.0 International License (http://creativecommons.org/licenses/by/4.0/), which permits unrestricted use, distribution, and reproduction in any medium, provided you give appropriate credit to the original author(s) and the source, provide a link to the Creative Commons license, and indicate if changes were made. The Creative Commons Public Domain Dedication waiver (http://creativecommons.org/publicdomain/zero/1.0/) applies to the data made available in this article, unless otherwise stated. 